Setiahani, et al/Jurnal Ekonomi Syariah Teori dan Terapan Vol. 6 No. 7 Juli 2019: 1331-1347;

PERBANDINGAN KINERJA KEUANGAN BERDASARKAN KATEGORI BUKU

\title{
PERBANDINGAN KINERJA KEUANGAN BERDASARKAN KATEGORI BUKU 1
}

\author{
Irena Anindita Setiahani \\ Departemen Ekonomi Syariah - Fakultas Ekonomi dan Bisnis - Universitas Airlangga \\ Email: irena-a-s-11@feb.unair.ac.id
}

Raditya Sukmana

Departemen Ekonomi Syariah - Fakultas Ekonomi dan Bisnis - Universitas Airlangga

Email: raditya-s@feb.unair.ac.id

\begin{abstract}
:
The existence of a financial intermediary institution (banking) is very important in a modern economic system. Banking as a business entity engaged in the field of finance or financial needs trust from customers to support and facilitate the activities it does. This study aims to determine the presence or absence of CAR, BOPO, LDR, ROA differences between syariah banks in the book category 1 and book 2.. Population in this research is 11 syariah Commercial Banks in Indonesia year 2015-2017. Given the number of population is still within the range of research, the sampling is done by census method, that is, the entire population member as the research sample. The analysis technique used is independent-samples t test. The test results indicate that there is a difference of Capital Adequacy Ratio between Book 1 and Book 2 on Sharia Public Bank which go public. So it can be concluded that there is a difference between the average CAR between Book 1 and Book 2 on Sharia Public Bank which go public. There is a difference of Operational Expense to Operational Income between Book 1 and Book 2 at the Public Bank of Sharia which go public. So it can be concluded that there is an average difference between BOPO Book 1 and Book 2 on the Sharia Public Bank which go public. There is a difference of Loan to Deposits Ratio between Book 1 and Book 2 on the Sharia Public Bank which goes public. So it can be concluded that there is a difference between the average LDR between Book 1 and Book 2 on Sharia Public Bank which go public. There is no difference in Return On Assets between Book 1 and Book 2 on Sharia Public Banks that go public. So it can be concluded that there is no difference in average ROA between Book 1 and Book 2 on Sharia Public Bank which go public.

Keywords: Capital Adequacy Ratio, Operational Expense to Operating Income, Loan to Deposits Ratio, and Return On Assets
\end{abstract}

\section{PENDAHULUAN}

Perbankan sebagai badan usaha yang bergerak di bidang keuangan atau finansial sangat membutuhkan kepercayaan dari para nasabah guna mendukung dan memperlancar kegiatan yang dilakukannya. Lancarnya kegiatan yang dilakukan oleh bank akan sangat mendukung dalam mencapai kesejahteraan para stakeholder dan dapat pula meningkatkan kinerjanya.
Pada tahun 1998 muncul UndangUndang No. 10 tahun 1998 atas perubahan Undang-Undang No. 7 tahun 1992 tentang perbankan. Sejak diberlakukanya Undang-undang Perbankan No. 10 tahun 1998, industri perbankan di Indonesia terbagi menjadi bank yang beroperasi berdasarkan bunga (yang disebut bank konvensional) dan bank yang beroperasi berdasarkan prinsip bagi hasil atau syariah islam (disebut dengan bank syariah). Undang-Undang

\footnotetext{
1 Jurnal ini merupakan bagian dari skripsi Irena Anindita Setiahani, NIM: 041114101, yang diuji pada tanggal 15 Januari 2018.
} 
No. 10 Tahun 1998 disebutkan dengan tegas istilah atauprinsip syariah yaitu bank berdasarkan prinsip syariah. Karena operasinya berpedoman ketentuanketentuan Syariah Islam, maka bank Islam disebut Bank Syariah. Berdasarkan Undang-Undang No. 10 Tahun 1998, bank dalam melakukan kegiatannya tidak hanya memperhatikan prinsip syariah saja tetapi juga harus memperhatikan ramburambu ketentuan Bank Indonesia atas terjadinya usaha yang dilakukan oleh bank. Penetapan rambu-rambu ketentuan dari BI bertujuan agar bank sebagai financial intermediary institution yang melakukan kegiatan usaha mendapatkan keuntungannya harus selalu dengan cara yang sesuai Syariah Islam.

Dalam meningkatkan profitabilitas maka bank harus memliki manajemen dan yang baik. Manajemen dana adalah suatu proses pengelolaan penghimpunan dana-dana dari masyarakat dan disalurkan kembali kepada masyarakat berupa kredit atau bentuk-bentuk lainnya demi mencapai tingkat rentabilitas yang memadai.

Tujuan penelitian yang ingin dicapai dalam penelitian ini adalah untuk mengetahui apakah ada perbandingan antara CAR, ROA, LDR, BOPO antara kategor ibuku 1 dan buku 2.

\section{LANDASAN TEORI}

\section{Kinerja Perbankan}

Kinerja merupakan hal penting yang harus dicapai oleh setiap perusahaan/perbankan dimana pun, karena kinerja merupakan cerminan dari kemampuan perusahaan dalam mengelola dan mengalokasikan sumber dayanya. Selain itu, tujuan pokok penilaian kinerja adalah untuk memotivasi karyawan dalam mencapai sasaran organisasi dan dalam memenuhi standar perilaku yang telah ditetapkan sebelumnya, agar membuahkan tindakan dan hasil yang diharapkan. Standar perilaku dapat berupa kebijakan manajemen atau rencana formal yang dituangkan dalam anggaran (Pradiksa, 2012:29).

Kinerja perusahaan dapat dinilai melalui berbagai macam variabel atau indikator, antara lain melalui laporan keuangan perusahaan yang bersangkutan. Berdasarkan laporan keuangan ini dapat dihitung sejumlah rasio keuangan yang umum digunakan sebagai dasar di dalam penilaian kinerja perusahaan. Menurut Merkusiwati (2007) dalam Ponco (2008:15), penilaian kinerja perusahaan bagi manajemen dapat diartikan sebagai penilaian terhadap prestasi yang dapat dicapai. Dalam hal ini laba dapat digunakan sebagai ukuran dari prestasi yang dicapai dalam suatu perusahaan.

\section{Capital Adequacy Ratio (CAR)}

Capital Adequacy Ratio adalah rasio bank untuk menunjang aktiva yang mengandung atau menghasilkan risiko, misalnya kredit yang diberikan. 
(Dendawijaya, 2003:122). Rasio ini dapat dirumuskan sebagai berikut:

$$
C A R=\frac{\text { Modal Sendiri }}{\text { ATMR }} X 100 \%
$$

Berdasarkan ketentuan Bank Indonesia No. 10/15/PBI/2008, bank dinyatakan termasuk sebagai bank yang sehat harus memiliki CAR paling sedikit sebesar 8\%. Hal ini didasarkan kepada ketentuan yang ditetapkan oleh BIS (Bank for International Settlement). CAR menunjukkan sejauh mana penurunan asset bank masih dapat ditutup oleh equity bank yang tersedia, semakin tinggi CAR semakin baik kondisi sebuah bank (Tarmidzi Achmad, 2003 dalam Nusantara, 2009:14). Perhitungan Capital Adequacy didasarkan pada prinsip bahwa setiap penanaman yang mengandung risiko harus disediakan jumlah modal sebesar persentase tertentu terhadap jumlah penanamannya. Semakin tinggi CAR maka keuntungan bank juga semakin besar. Dengan kata lain, semakin kecil risiko suatu bank maka semakin besar keuntungan yang diperoleh bank. Seperti diketahui CAR juga biasa disebut dengan rasio kecukupan modal, yang berarti jumlah modal sendiri yang diperlukan untuk menutup risiko serta membiayai seluruh benda tetap dan inventaris bank.

Semakin tinggi CAR maka keuntungan bank juga semakin besar. Dengan kata lain, semakin kecil risiko suatu bank maka semakin besar keuntungan yang diperoleh bank. Semakin tinggi CAR maka semakin besar pula sumber daya finansial yang dapat digunakan untuk keperluan pengembangan usaha dan mengantisipasi potensi kerugian yang diakibatkan oleh penyaluran kredit.

\section{Return On Assets (ROA)}

Menurut Horne dan Wachowicz (2005:235), "ROA mengukur efektivitas keseluruhan dalam menghasilkan laba melalui aktiva yang tersedia; daya untuk menghasilkan laba dari modal yang diinvestasikan". Horne dan Wachowicz menghitung ROA dengan menggunakan rumus laba bersih setelah pajak dibagi dengan total aktiva.

Semakin besar nilai ROA, menunjukkan kinerja perusahaan yang semakin baik pula, karena tingkat pengembalian investasi semakin besar. "Nilai ini mencerminkan pengembalian perusahaan dari seluruh aktiva (atau pendanaan) yang diberikan pada perusahaan" (Wild, Subramanyam, dan Halsey, 2005:65). Rumus untuk menghitung ROa adalah

$$
R O A=\frac{\text { LabaBersih Sebelum Pajak }}{\text { Total Aset }} X 100 \%
$$

\section{Biaya Operasional terhadap Pendapatan} Operasional (BOPO)

Perusahaan yang bergerak dibidang perbankan, melakukan efisiensi operasi, yaitu untuk mengetahui apakah bank dalam opersinya yang berhubungan dengan usaha pokok bank, dilakukan 
dengan benar dalam arti sesuai yang diharapkan manajemen dan pemegang saham (Hanley, 1997 dalam Sudiyatno, 2010:6). Biaya operasional merupakan semua biaya yang berhubungan langsung dengan kegiatan usaha bank yang diperinci sebagai berikut: biaya bunga, biaya valuta asing lainnya, biaya tenaga kerja, penyusutan, biaya lainnya. Pendapatan operasional merupakan semua pendapatan yang merupakan hasillangsung dari kegiatan usaha bank secara terperinci adalah sebagai berikut: hasil bunga, provisi dan komisi, pendapatan valuta asing lainnya, pendapatan lainnya (Dendawijaya, 2003:113). Rasio ini dirumuskan sebagai berikut (SE BI No 6/73/INTERN DPNP tgl 24 Desember 2004):

$$
B O P O=\frac{\text { Belanja Operasional }}{\text { Pendapatan Operasional }} \times 100 \%
$$

Semakin kecil rasio ini berarti semakin efisien biaya operasional yang dikeluarkan bank yang bersangkutan (Almilia dan Herdiningtyas, 2005 dalam Setyarini, 2009:27). Semakin efisien bank dalam menjalankan aktivitas usahanya maka laba yang dicapai bank semakin meningkat. Menurut ketentuan Bank Indonesia BOPO normal berkisar antara 94\% sampai 96\% (Setyarini, 2009:27).

\section{Finance Deposit Ratio (FDR)}

$$
\text { Loan to Deposit Ratio (LDR) }
$$

Dendawijaya (2003:118) merupakan rasio antara seluruh jumlah kredit yang diberikan bank dengan dana yang diterima oleh bank. LDR tersebut menyatakan seberapa jauh kemampuan bank dalam membayar kembali penarikan dana yang dilakukan deposan dengan mengandalkan kredit yang diberikan sebagai sumber likuiditasnya.

Menurut Surat Edaran Bank Indonesia Nomor 6/23/DPNP tanggal 1 Mei 2004, rasio ini dapat dirumuskan sebagai berikut:

$$
F D R=\frac{\text { Pembiayayaan }}{\text { DanaPihak Ketiga }} X 100 \%
$$

Total kredit yang dimaksud adalah kredit yang diberikan kepada pihak ketiga (tidak termasuk kredit kepada bank lain). Jika bank mempunyai LDR yang sangat tinggi, maka bank akan mempunyai risiko tidak tertagihnya pinjaman yang tinggi pada titik tertentu bank akan mengalami kerugian (Susilo, 2000 dalam Anindita, 2011).

\section{Hipotesis}

1. Terdapat perbedaan CAR antara bank syariah dalam kategori buku 1 dan buku 2.

2. Terdapat perbedaan BOPO antara bank syariah dalamkategori buku 1 dan buku 2.

3. Terdapat perbedaan LDR antara bank syariah dalamkategori buku 1 dan buku 2.

4. Terdapat perbedaan ROA antara bank syariah dalam kategori buku 1 dan buku 2.

Model analisis dalam penelitian ini dapat dilihat dalam Gambar 1 berikut ini : 


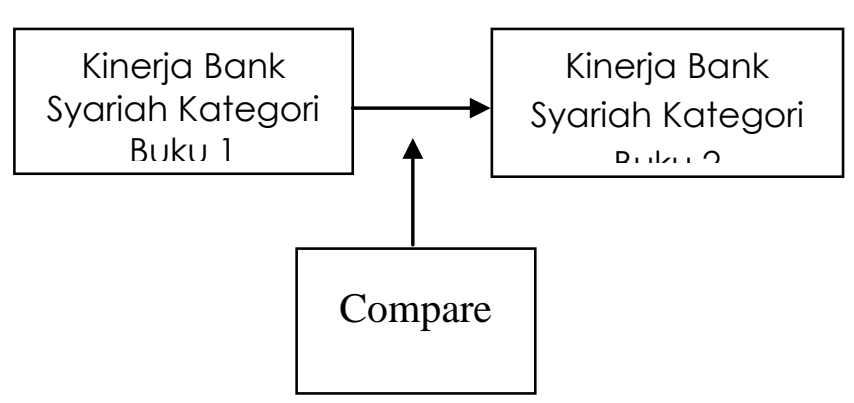

Gambar 1.

Model Analisis

III. METODE PENELITIAN

Penelitian ini menggunakan pendekatan penelitian kuantitatif yaitu untuk menjawab rumusan masalah serta tujuan penelitian yaitu perbedaan CAR, ROA, BOPO, FDR antara bank syariah kategori buku 1 dan buku 2. Pengolahan data penelitian ini dengan cara melakukan uji beda terhadap CAR buku 1 dan buku 2, ROA buku 1 dan buku 2, BOPO buku 1 dan buku 2, FDR buku 1 dan buku 2.

\section{Definisi Operasional}

\section{Capital Adequency Ratio (CAR)}

Capital Adequency Ratio (CAR) adalah rasio untuk menunjukan kemampuan bank dalam menyediakan dana untuk mengatasi kemungkinan kerugian. laporan keuangan yang dipublikasikan kepada nasabah dalam penelitian ini diperoleh dari statistik perbankan syariah yang telah di publish pada website resmi otoritas jasa keuangan sebagai kinerja keuangan bank umum syariah periode Januari 2015 hingga Juni 2017 dan data penelitian ini diukur dengan menggunakan data nominal dalam milyar rupiah berskala rasio

\section{Biaya Operasional Pendapatan Operasional (BOPO)}

Biaya operasional pendapatan operasional adalah biaya operasional yang dikeluarkan berupa biaya bunga yang akan diberikan kepada nasabah sedangkan pendapatan operasional yaitu bunga yang didapatkan dari nasabah. Nominal BOPO dapat dilihat dalam laporan keuangan yang dipublikasikan kepada nasabah dalam penelitian ini diperoleh dari statistik perbankan syariah yang telah di publish pada website resmi otoritas jasa kevangan sebagai kinerja keuangan bank umum syariah periode Januari 2015 hingga Juni 2017 dan data penelitian ini diukur dengan menggunakan data nominal dalam milyar rupiah berskala rasio

\section{Financing Deposit Ratio (FDR)}

$$
\text { Financing Deposit Ratio }
$$
merupakan rasio likuiditas yang berfungsi untuk memenuhi kewajiban jangka pendek dengan membagi total kredit terhadap total dana pihak ketiga (DPK). Likuiditas perbankan harus dikelola dengan baik guna memenuhi kebutuhan saat nasabah mengambil dananya. Nominal FDR dapat dilihat dalam laporan keuangan yang dipublikasikan kepada nasabah dalam penelitian ini diperoleh dari statistik perbankan syariah yang telah di publish pada website resmi otoritas jasa keuangan sebagai kinerja keuangan bank umum syariah periode Januari 2015 hingga Juni 2017 dan data penelitian ini 
Setiahani, et al/Jurnal Ekonomi Syariah Teori dan Terapan Vol. 6 No. 7 Juli 2019: 1331-1347; PERBANDINGAN KINERJA KEUANGAN BERDASARKAN KATEGORI BUKU

diukur dengan menggunakan data nominal dalam milyar rupiah berskala rasio

\section{Return On Assets (ROA)}

Return On Assets adalah rasio untuk mengukur kemampuan bank dalam menghasilkan profit yang biasa disebut dengan profitabilitas. Untuk melihat seberapa efektif perbankan tersebut menggunakan asetnya sehingga mendapat laba. Nominal ROA dapat dilihat dalam laporan kevangan yang dipublikasikan kepada nasabah dalam penelitian ini diperoleh dari statistik perbankan syariah yang telah di publish pada website resmi otoritas jasa kevangan sebagai kinerja keuangan bank umum syariah periode Januari 2015 hingga Juni 2017 dan data penelitian ini diukur dengan menggunakan data nominal dalam milyar rupiah berskala rasio

\section{Populasi dan Sampel}

Populasi adalah wilayah generalisasi yang terdiri atas obyek atau subyek yang mempunyai kualitas dan karakteristik tertentu yang ditetapkan oleh peneliti untuk dipelajari dan kemudian ditarik kesimpulannya (Sugiyono, 2011:85). Populasi dalam penelitian ini adalah 11 Bank Umum Syariah di Indonesia tahun 2015-2017. Mengingat jumlah populasi masih dalam jangkauan penelitian maka penarikan sampel dilakukan dengan metode sensus, yaitu keseluruhan anggota populasi sebagai sampel penelitian. Periode yang digunakan adalah periode bulanan mulai tahun 2015 hingga tahun 2017.

\section{Teknik Analisis}

Pendekatan yang digunakan dalam penelitian adalah pendekatan kuantitatif, yaitu menganalisis pengukuran fenomena ekonomi yang merupakan gabungan antara teori ekonomi (informasi laporan kevangan) dan model statistika yang diklasifikasikan dalam kategori tertentu dengan menggunakan tabeltabel, dengan tahap-tahap analisis sebagai berikut:

1. Menghitung variabel-variabel yang akan diteliti yaitu CAR, ROA, BOPO, dan LDR pada laporan kinerja kevangan bank syariah di dasarkan pada pengelompokan BUKU selama periode yang telah ditentukan yaitu 2015-2017.

2. Melakukan uji hipotesis:

a. Merumuskan hipotesis statistik.

$$
\begin{aligned}
H_{0}: & \overline{\operatorname{CAR}}_{(K B 1)}=\overline{\mathrm{CAR}}_{(\mathrm{KB} 2)}, \text { (CAR } \\
& \text { kelompok bukU } 1 \text { sama } \\
& \text { dengan CAR kelompok bukU } \\
& \text { 2). }
\end{aligned}
$$

$$
\begin{aligned}
\mathrm{H}_{\mathrm{A}}: & \overline{\mathrm{CAR}}_{(K B 1)}>\overline{\mathrm{CAR}}_{(\mathrm{KB} 2)}, \text { (CAR } \\
& \text { kelompok bukU } 1 \text { berbeda } \\
& \text { dengan CAR kelompok buku } \\
& \text { 2). }
\end{aligned}
$$

$\mathrm{H}_{0}$ :

\footnotetext{
$\overline{\mathrm{BOPO}}_{(K B 1)}=\overline{\mathrm{BOPO}}_{(\mathrm{KB} 2)}$ , (BOPO kelompok buku 1 sama dengan BOPO kelompok buku 2).
} 
$\mathrm{H}_{\mathrm{A}}$ :

$\overline{\mathrm{BOPO}}_{(K B 1)}>\overline{\mathrm{BOPO}}_{(\mathrm{KB} 2)}$
, (BOPO kelompok buku 1
berbeda dengan BOPO
kelompok buku 2).

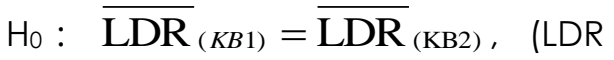
kelompok buku 1 sama dengan LDR kelompok bukU 2).

$$
\begin{aligned}
\mathrm{H}_{\mathrm{A}}: & \overline{\mathrm{LDR}}_{(K B 1)}>\overline{\mathrm{LDR}}_{(\mathrm{KB} 2)},(\mathrm{LDR} \\
& \text { kelompok buku } 1 \text { berbeda } \\
& \text { dengan LDR kelompok buku } \\
& \text { 2). }
\end{aligned}
$$

$\mathrm{H}_{0}: \overline{\mathrm{ROA}}_{(K B 1)}=\overline{\mathrm{ROA}}_{(\mathrm{KB} 2)}, \quad(\mathrm{ROA}$ kelompok buku 1 sama dengan ROA kelompok buku 2).

$$
\begin{aligned}
\mathrm{H}_{\mathrm{A}}: & \overline{\operatorname{ROA}}_{(K B 1)}>\overline{\mathrm{ROA}}_{(\mathrm{KB} 2)}, \quad(\mathrm{ROA} \\
& \text { kelompok bukU } 1 \text { berbeda } \\
& \text { dengan ROA kelompok buku } \\
& \text { 2). }
\end{aligned}
$$

b. Menentukan level of significant (LOS) sebesar $5 \%$.

c. Pengambilan keputusan Jika nilai Sign. $<\alpha$ (los $=5 \%$ ), menolak hipotesis nol $\left(\mathrm{H}_{0}\right)$ Jika nilai Sign. $>\alpha$ (los $=5 \%)$, gagal menolak hipotesis nol $\left(\mathrm{H}_{0}\right)$.

\section{HASIL DAN PEMBAHASAN}

\section{Deskripsi Variabel}

Hasil perhitungan masing-masing variabel disajikan pada Tabel 1 berikut:
Tabel 1.

Deskripsi Variabel Penelitian

\begin{tabular}{|l|c|c|c|c|}
\hline \multicolumn{1}{|c|}{ Variabel } & Maximum & Minimum & Mean & $\mathbf{N}$ \\
\hline CAR Buku 1 & 26,27 & 16,69 & 19,32 & 30 \\
\hline CAR Buku 2 & 18,09 & 13,37 & 15,58 & 30 \\
\hline BOPO Buku 1 & 136,25 & 78,35 & 99,61 & 30 \\
\hline BOPO Buku 2 & 97,23 & 87,89 & 93,27 & 30 \\
\hline FDR Buku 1 & 100,40 & 89,20 & 95,03 & 30 \\
\hline FDR Buku 2 & 93,35 & 83,04 & 89,32 & 30 \\
\hline ROA Buku 1 & 5,83 & 0,03 & 1,25 & 30 \\
\hline ROA Buku 2 & 1,47 & 0,46 & 0,89 & 30 \\
\hline
\end{tabular}

Sumber: Data, Diolah

Dari Tabel 1 dapat diketahui Capital Adequacy Ratio (CAR) pada Buku 1 Bank umum syariah yang terdaftar di Bursa Efek Indonesia (BEI) menunjukkan nilai rata-rata sebesar 19,32. Hal ini nampak pada nilai minimum CAR sebesar 16,69 terdapat pada bulan Mei tahun 2016, hal ini berarti bahwa pada bulan Mei tahun 2016 Bank umum syariah yang tergabung di Buku 1 belum dapat memaksimalkan kecukupan modalnya guna menanggulangi resiko kerugian. Nilai CAR tertinggi sebesar 26,27 terdapat pada bulan September tahun 2015, hal ini berarti bahwa pada bulan September tahun 2015 Bank umum syariah yang tergabung di Buku 1 memiliki kemampuan mencukupi modalnya guna menanggulangi resiko kerugian.

Capital Adequacy Ratio (CAR) pada Buku 2 Bank umum syariah yang terdaftar di Bursa Efek Indonesia (BEI) menunjukkan nilai rata-rata sebesar 15,58. Hal ini nampak pada nilai minimum CAR sebesar 13,37 terdapat pada bulan Juni tahun 2015, hal ini berarti bahwa pada bulan Juni tahun 2015 Bank umum syariah 
Setiahani, et al/Jurnal Ekonomi Syariah Teori dan Terapan Vol. 6 No. 7 Juli 2019: 1331-1347; PERBANDINGAN KINERJA KEUANGAN BERDASARKAN KATEGORI BUKU

yang tergabung di Buku 2 belum dapat memaksimalkan kecukupan modalnya guna menanggulangi resiko kerugian. Nilai CAR tertinggi sebesar 18,09 terdapat pada bulan September tahun 2015, hal ini berarti bahwa pada bulan Maret tahun 2017 Bank umum syariah yang tergabung di Buku 2 memiliki kemampuan mencukupi modalnya guna menanggulangi resiko kerugian.

Biaya Operasional Pendapatan Operasional (BOPO) pada Buku 1 Bank umum syariah yang terdaftar di Bursa Efek Indonesia (BEI) menunjukkan nilai rata-rata sebesar 99,61. Hal ini nampak pada nilai minimum BOPO sebesar 78,35 terdapat pada bulan Februari tahun 2017, hal ini berarti bahwa pada bulan Februari tahun 2017 Bank umum syariah yang tergabung di Buku 1 biaya operasional lebih rendah dari pendapatan yang diterima oleh Bank umum syariah tersebut sehingga pada bulan tersebut Bank umum syariah yang tergabung di Buku 1 mampu mengefisiensikan biaya operasionalnya. Nilai BOPO tertinggi sebesar 136,25 terdapat pada bulan Mei tahun 2016, hal ini berarti bahwa pada bulan Mei tahun 2016 Bank umum syariah yang tergabung di Buku 1 memiliki pendapatan yang rendah dari biaya operasionalnya sehingga pada bulan tersebut Bank umum syariah yang tergabung di Buku 1 belum mampu mengefisiensikan biaya operasionalnya.

Biaya Operasional Pendapatan Operasional (BOPO) pada Buku 2 Bank umum syariah yang terdaftar di Bursa Efek Indonesia (BEI) menunjukkan nilai rata-rata sebesar 93,27. Hal ini nampak pada nilai minimum BOPO sebesar 89,89 terdapat pada bulan Mei dan Juni tahun 2017, hal ini berarti bahwa pada bulan Mei dan Juni tahun 2017 Bank umum syariah yang tergabung di Buku 2 biaya operasional lebih rendah dari pendapatan yang diterima oleh Bank umum syariah tersebut sehingga pada bulan tersebut Bank umum syariah yang tergabung di Buku 2 mampu mengefisiensikan biaya operasionalnya. Nilai BOPO tertinggi sebesar 97,23 terdapat pada bulan Juli tahun 2015, hal ini berarti bahwa pada bulan Juli tahun 2015 Bank umum syariah yang tergabung di Buku 2 memiliki pendapatan yang rendah dari biaya operasionalnya sehingga pada bulan tersebut Bank umum syariah yang tergabung di Buku 2 belum mampu mengefisiensikan biaya operasionalnya.

Financing Deposit Ratio (FDR) pada BukU 1 Bank umum syariah yang terdaftar di Bursa Efek Indonesia (BEI) menunjukkan nilai rata-rata sebesar 95,03. Hal ini nampak pada nilai minimum FDR sebesar 89,20 terdapat pada bulan Maret tahun 2017, hal ini berarti bahwa pada bulan Maret tahun 2017 Bank umum syariah yang tergabung di Buku 1 jumlah kredit yang dikeluarkan oleh Bank umum syariah sangat rendah. Nilai FDR tertinggi sebesar 100,40 terdapat pada bulan November tahun 2016, hal ini berarti bahwa pada bulan November tahun 2016 
Setiahani, et al/Jurnal Ekonomi Syariah Teori dan Terapan Vol. 6 No. 7 Juli 2019: 1331-1347; PERBANDINGAN KINERJA KEUANGAN BERDASARKAN KATEGORI BUKU

Bank umum syariah yang tergabung di Buku 1 mengeluarkan jumlah kredit yang cukup tinggi.

Financing Deposit Ratio (FDR) pada Buku 2 Bank umum syariah yang terdaftar di Bursa Efek Indonesia (BEI) menunjukkan nilai rata-rata sebesar 89,32. Hal ini nampak pada nilai minimum FDR sebesar 83,04 terdapat pada bulan Mei tahun 2017, hal ini berarti bahwa pada bulan Mei tahun 2017 Bank umum syariah yang tergabung di Buku 2 jumlah kredit yang dikeluarkan oleh Bank umum syariah sangat rendah. Nilai FDR tertinggi sebesar 93,35 terdapat pada bulan Juni tahun 2016, hal ini berarti bahwa pada bulan Juni tahun 2016 Bank umum syariah yang tergabung di Buku 2 mengeluarkan jumlah kredit yang cukup tinggi.

Return on Assets (ROA) pada Buku 1 Bank umum syariah yang terdaftar di Bursa Efek Indonesia (BEI) menunjukkan nilai rata-rata sebesar 1,25 . Hal ini nampak pada nilai minimum ROA sebesar 0,03 terdapat pada bulan Juni tahun 2017, hal ini berarti bahwa pada bulan Juni tahun 2017 Bank umum syariah yang tergabung di Buku 1 menghasilkan laba yang sangat rendah. Nilai ROA tertinggi sebesar 5,83 terdapat pada bulan Mei tahun 2016, hal ini berarti bahwa pada bulan Mei tahun 2016 Bank umum syariah yang tergabung di Buku 1 mampu menghasilkan laba yang cukup tinggi.

Return on Assets (ROA) pada Buku 2 Bank umum syariah yang terdaftar di Bursa Efek Indonesia (BEI) menunjukkan nilai rata-rata sebesar 0,89. Hal ini nampak pada nilai minimum ROA sebesar 0,46 terdapat pada bulan November tahun 2015, hal ini berarti bahwa pada bulan November tahun 2015 Bank umum syariah yang tergabung di Buku 2 menghasilkan laba yang sangat rendah. Nilai ROA tertinggi sebesar 1,47 terdapat pada bulan Mei tahun 2017, hal ini berarti bahwa pada bulan Mei tahun 2017 Bank umum syariah yang tergabung di Buku 2 mampu menghasilkan laba yang cukup tinggi.

\section{Hasil Uji Beda}

\section{Capital Adequacy Ratio (CAR)}

Berdasarkan hasil pengolahan data, maka hasil perbandingan CAR antara Buku 1 dan Buku 2 pada Bank Umum Syariah yang go publik adalah sebagai berikut:

Tabel 2.

Hasil Uji Beda CAR antara Buku 1 dan Buku 2 Pada Bank Umum Syariah Go Publik

\begin{tabular}{|l|r|l|r|}
\hline \multicolumn{2}{|c|}{ Buku 1 } & \multicolumn{2}{c|}{ Buku 2 } \\
\hline \hline Rata-Rata & 19,32 & Rata-Rata & 15,58 \\
\hline SD & 1,94 & SD & 1,64 \\
\hline t-hitung & $=8,067$ & \\
\hline t-tabel & $=2,052$ \\
\hline Sign. & $=0,000$ \\
\hline
\end{tabular}

Sumber: data diolah

Pengujian independen t-tes dapat diketahui dari hasil output spss. Nilai signifikansi yang digunakan sebesar $5 \%$ atau 0,05. Kemudian menentukan nilai thitung dapat dilihat dari output tabel diatas (Independent Sampel Test) yaitu sebesar 8,067 dan nilai tabel dapat sebesar 1,671. Dapat diketahui bahwa nilai thitung $>t_{\text {tabel }}$ 
$(8,067>1,671)$ maka $\mathrm{H}_{\mathrm{a}}$ diterima dan $\mathrm{H}_{0}$ ditolak. Jadi dapat disimpulkan bahwa ada perbedaan rata-rata CAR antara Buku 1 dan Buku 2 pada Bank Umum Syariah yang go publik. Nilai rata-rata CAR dari Buku 1 sebesar 19,32 sedangkan nilai rata-rata CAR dari BukU 2 sebesar 15,58. Jadi nilai rata-rata CAR Buku 1 lebih baik dari pada nilai rata-rata CAR BukU 2. Hal ini menandakan bahwa modal yang dimiliki oleh Bank Umum Syariah yang go publik tergabung dalam Buku 1 telah tercukupi untuk menutupi risiko kerugian yang kemungkinan dihadapi oleh Bank Umum Syariah yang go publik tergabung dalam Buku 1 bila dibandingkan dengan Bank Umum Syariah yang go publik tergabung dalam Buku 2. Semakin tinggi CAR maka semakin baik kemampuan bank tersebut untuk menanggung risiko dari setiap kredit/aktiva produktif yang berisiko, sebaliknya semakin rendah CAR maka semakin tidak mampu bank tersebut untuk menanggung risiko dari setiap kredit/aktiva produktif yang berisiko. Jika nilai CAR tinggi maka bank tersebut mampu membiayai kegiatan operasional dan memberikan kontribusi yang cukup besar bagi profitabilitas.

Nilai rata-rata aktiva tertimbang menurut risiko Bank Umum Syariah yang go publik tergabung dalam Buku 1 dan Buku 2 seperti pada Tabel dibawah ini

Tabel 3.

\section{Rata-Rata Aktiva Tertimbang menurut}

Risiko antara Buku 1 dan Buku 2

\begin{tabular}{|c|c|c|c|c|c|c|c|c|c|}
\hline \multirow[t]{2}{*}{ Keterangan } & \multicolumn{4}{|c|}{ Tahun 2015} & \multicolumn{2}{|c|}{ Tahun 2016} & \multicolumn{3}{|c|}{ Tahun 2017} \\
\hline & & Rata-rata ATMR & & $\begin{array}{l}\text { Rata-rata } \\
\text { Modal }\end{array}$ & $\begin{array}{l}\text { Rata-rata } \\
\text { ATMR }\end{array}$ & $\begin{array}{l}\text { Rata-rata } \\
\text { Modal }\end{array}$ & & $\begin{array}{l}\text { Rata-rata } \\
\text { ATMR }\end{array}$ & $\begin{array}{l}\text { Rata-rata } \\
\text { Modala }\end{array}$ \\
\hline Buku 1 & $\mathrm{Rp}_{\mathrm{p}}$ & 849.016.865 & $\mathrm{Rp}$ & 655.546 .143 & \begin{tabular}{|l|l|}
$\operatorname{Rp} \quad 517.920 .652$ \\
\end{tabular} & Rp 729.922.143 & $\mathrm{Rp}$ & 507.358 .330 & $\begin{array}{lr}\operatorname{Rp} & 894.000 .000\end{array}$ \\
\hline Buku 2 & $\mathrm{Rp}$ & 1.891.668.183 & & 1.393.239.250 & Rp 1.924.186.995 & Rp 1.643.239.250 & & 5.367 .133 .000 & Rp 9.578.080.000 \\
\hline
\end{tabular}

Sumber: data diolah penulis

Dari Tabel diatas dapat dilihat bahwa rata-rata aktiva tertimbang menurut risiko Bank Umum Syariah yang go publik tergabung dalam Buku 1 tahun 2015 sebesar Rp 849.016.865.360 dan Rp 517.920.651.766 tahun 2016 sedangkan tahun 2017 sebesar Rp 507.358.330.000, sedangkan modal usaha yang dimiliki sebesar Rp 655.546.142.857 untuk tahun 2015 dan tahun 2016 sebesar $\mathrm{Rp}$ 729.922.142.857, sedangkan tahun 2017 sebesar Rp 894.000.000.000. Hal ini menandakan bahwa aktiva yang dimiliki oleh Bank Umum Syariah yang go publik tergabung dalam Buku 1 selama dua tahun melebihi dari modal usaha yang dimiliki sehingga Bank Umum Syariah yang go publik tergabung dalam Buku 1 memiliki kecukupan modal apabila Bank Umum Syariah yang go publik tergabung dalam Buku 1 mengalami kebangkrutan dan kegiatan operasional yang dibiayai sangat rendah serta dapat memberikan kontribusi yang cukup besar bagi profitabilitas perusahaan.

Rata-rata aktiva tertimbang menurut risiko Bank Umum Syariah yang go publik tergabung dalam Buku 2 tahun 2015 sebesar Rp 1.891.668.182.500 dan Rp 1.924.186.995.000 tahun 2016, sedangkan tahun 2017 sebesar Rp 5.367.133.000.000. Modal usaha yang dimiliki sebesar Rp 1.393.239.250.000 untuk tahun 2015 dan 
Setiahani, et al/Jurnal Ekonomi Syariah Teori dan Terapan Vol. 6 No. 7 Juli 2019: 1331-1347; PERBANDINGAN KINERJA KEUANGAN BERDASARKAN KATEGORI BUKU

tahun 2016 sebesar Rp 1.643.239.250.000, serta tahun 2017 sebesar Rp 9.578.080.000.000. Hal ini menandakan bahwa aktiva tertimbang menurut risiko yang dimiliki oleh Bank Umum Syariah yang go publik tergabung dalam Buku 2 melebihi dari penyaluran modal usaha yang dimilikinya sehingga Bank Umum Syariah yang go publik tergabung dalam Buku 2 memiliki kecukupan modal yang sangat kecil dan kegiatan operasional yang dibiayai cukup besar serta kurang memberikan kontribusi yang cukup besar bagi profitabilitas perusahaan.

\section{Biaya Operasional Terhadap Pendapatan Operasional (BOPO)}

Berdasarkan hasil pengolahan data, maka hasil perbandingan BOPO antara Buku 1 dan Buku 2 pada Bank Umum Syariah yang go publik adalah sebagai berikut:

Tabel 4.

Hasil Uji Beda BOPO antara Buku 1 dan

Buku 2 pada Bank Umum Syariah Go

Publik

\begin{tabular}{|l|r|l|r|}
\hline \multicolumn{2}{|c|}{ Buku 1 } & \multicolumn{2}{c|}{ Buku 2 } \\
\hline \hline Rata-Rata & 99,61 & Rata-Rata & 93,27 \\
\hline SD & 11,02 & SD & 2,96 \\
\hline t-hitung & $=3,042$ \\
\hline t-tabel & $=2,052$ \\
\hline Sign. & $=0,004$ \\
\hline
\end{tabular}

Sumber: data diolah

Pengujian independen t-tes dapat diketahui dari hasil output spss. Nilai signifikansi yang digunakan sebesar $5 \%$ atau 0,05. Kemudian menentukan nilai thitung dapat dilihat dari output tabel diatas (Independent Sampel Test) yaitu sebesar
3,042 dan nilai tabel dapat sebesar 1,671. Dapat diketahui bahwa nilai thitung $>t_{\text {tabel }}$ $(3,042>1,671)$ maka $\mathrm{H}_{a}$ diterima dan $\mathrm{H}_{0}$ ditolak. Jadi dapat disimpulkan bahwa ada perbedaan rata-rata BOPO antara Buku 1 dan Buku 2 pada Bank Umum Syariah yang go publik. Nilai rata-rata BOPO dari Buku 1 sebesar 99,61 sedangkan nilai rata-rata BOPO dari BukU 2 sebesar 93,27. Jadi nilai rata-rata BOPO Buku 1 kurang baik dari pada nilai ratarata BOPO BukU 2. Hal ini menandakan bahwa biaya operasional yang dimiliki oleh Bank Umum Syariah yang go publik tergabung dalam Buku 1 lebih besar dibandingkan dengan Bank Umum Syariah yang go publik tergabung dalam Buku 2. Hal ini menandakan bahwa Bank Umum Syariah yang go publik tergabung dalam BukU 1 belum efisiensi dalam menjalankan kegiatan operasionalnya. Semakin kecil nilai BOPO artinya semakin efisien perbankan dalam beroperasi, sebaliknya semakin besar nilai BOPO artinya semakin tidak efisien perbankan dalam beroperasi. Belanja operasional adalah biaya bunga yang diberikan pada nasabah sedangkan pendapatan operasional adalah bunga yang didapatkan dari nasabah.

Nilai rata-rata beban operasional menurut risiko Bank Umum Syariah yang go publik tergabung dalam Buku 1 dan Buku 2 seperti pada Tabel dibawah ini

Tabel 5.

Rata-Rata Beban Operasional antara Buku 1 dan Buku 2 
Setiahani, et al/Jurnal Ekonomi Syariah Teori dan Terapan Vol. 6 No. 7 Juli 2019: 1331-1347; PERBANDINGAN KINERJA KEUANGAN BERDASARKAN KATEGORI BUKU

\begin{tabular}{|c|c|c|c|c|c|c|}
\hline \multirow[t]{2}{*}{ Keterangan } & \multicolumn{2}{|c|}{ Tahun 2015} & \multicolumn{2}{|c|}{ Tahun 2016} & \multicolumn{2}{|c|}{$\begin{array}{l}\text { Tahun } 2017 \\
\end{array}$} \\
\hline & $\begin{array}{c}\text { Ratararat Beban } \\
\text { Operasional }\end{array}$ & $\begin{array}{l}\text { Ratar-atata } \\
\text { Pendapatann }\end{array}$ & $\begin{array}{l}\text { Ratatratab Beban } \\
\text { Operasional }\end{array}$ & $\begin{array}{l}\text { Ratar-ata } \\
\text { Pendapatan }\end{array}$ & 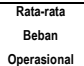 & $\begin{array}{l}\text { Retar-rata } \\
\text { Pendapatan }\end{array}$ \\
\hline Buku 1 & Rp 1.437.156 & $\begin{array}{ll}\operatorname{Rp} & 533.034\end{array}$ & $\begin{array}{ll}\operatorname{Rp} & 1.592 .742\end{array}$ & $\begin{array}{lll}R p & 582.487\end{array}$ & Rp 282.500 & $\begin{array}{lll}\text { Rpp } & 648.500\end{array}$ \\
\hline Buku2 & $\operatorname{Rpp} 1.061 .706$ & $\begin{array}{lll}R p & 2416 \cdot 243\end{array}$ & $\operatorname{Rp} \quad 1.1993 .340$ & $R p 2$ 2.388.603 & Rp 3.038 .800 & Rp 7.416 .000 \\
\hline
\end{tabular}

Sumber: data diolah penulis

Dari Tabel diatas dapat dilihat bahwa rata-rata beban operasional Bank Umum Syariah yang go publik tergabung dalam Buku 1 tahun 2015 sebesar Rp 1.437.155.891.399 dan Rp 1.592.741.667.857 tahun 2016 serta tahun 2017 sebesar Rp 282.500.000.000. Hal ini menandakan bahwa beban operasional yang harus ditanggung oleh Bank Umum Syariah yang go publik tergabung dalam Buku 1 selama dua tahun sangat besar sehingga Bank Umum Syariah yang go publik tergabung dalam Buku 1 kurang efisien dalam menjalankan aktivitas usahanya serta kurang memberikan kontribusi yang cukup besar bagi profitabilitas perusahaan.

Rata-rata beban operasional Bank Umum Syariah yang go publik tergabung dalam Buku 2 tahun 2015 sebesar Rp 1.061.706.257.513 dan Rp 1.193.339.857.201 tahun 2016, serta tahun 2017 sebesar Rp 3.038.800.000.000. Hal ini menandakan bahwa beban operasional yang harus ditanggung oleh Bank Umum Syariah yang go publik tergabung dalam Buku 2 selama dua tahun sangat rendah sehingga Bank Umum Syariah yang go publik tergabung dalam Buku 2 efisien dalam menjalankan aktivitas usahanya serta mampu memberikan kontribusi yang cukup besar bagi profitabilitas perusahaan.

\section{Loan to Deposit Ratio (LDR)}

Berdasarkan hasil pengolahan data, maka hasil perbandingan LDR antara Buku 1 dan Buku 2 pada Bank Umum Syariah yang go publik adalah sebagai berikut:

Tabel 6.

Hasil Uji Beda LDR antara Buku 1 dan Buku 2 Pada Bank Umum Syariah Go Publik

\begin{tabular}{|l|r|l|r|}
\hline \multicolumn{2}{|c|}{ Buku 1 } & \multicolumn{2}{c|}{ Buku 2 } \\
\hline \hline Rata-Rata & 95,03 & Rata-Rata & 89,32 \\
\hline SD & 3,39 & SD & 2,56 \\
\hline t-hitung & $=7,365$ \\
\hline t-tabel & $=2,052$ \\
\hline Sign. & $=0,000$ \\
\hline
\end{tabular}

Sumber: data diolah

Pengujian independen t-tes dapat diketahui dari hasil output spss. Nilai signifikansi yang digunakan sebesar 5\% atau 0,05. Kemudian untuk menentukan nilai thitung dapat dilihat dari output pada Tabel 4.4 (Independent Sampel Test) yaitu sebesar 7,365 dan nilai tabel dapat sebesar 1,671. Dapat diketahui bahwa nilai thitung $>$ $t_{\text {tabel }}(7,365>1,671)$ maka $\mathrm{H}_{\mathrm{a}}$ diterima dan Ho ditolak. Jadi dapat disimpulkan bahwa ada perbedaan rata-rata LDR antara Buku 1 dan Buku 2 pada Bank Umum Syariah yang go publik. Nilai rata-rata LDR dari Buku 1 sebesar 95,03 sedangkan nilai rata-rata LDR dari BukU 2 sebesar 89,32. Jadi nilai rata-rata LDR BUkU 1 kurang baik dari pada nilai rata-rata LDR BUkU 2. Hal ini menandakan bahwa Bank Umum Syariah yang go publik tergabung dalam Buku 1 tidak memiliki likuiditas yang cukup memadai untuk menutup kewajibannya 
Setiahani, et al/Jurnal Ekonomi Syariah Teori dan Terapan Vol. 6 No. 7 Juli 2019: 1331-1347; PERBANDINGAN KINERJA KEUANGAN BERDASARKAN KATEGORI BUKU

terhadap nasabah, sedangkan Bank Umum Syariah yang go publik tergabung dalam Buku 2 memiliki likuiditas yang cukup memadai tetapi mungkin pendapatannya lebih rendah, karena seperti yang diketahui dunia perbankan memperoleh pendapatan melalui kredit yang disalurkan. Likuiditas perbankan perlu dikelola guna memenuhi kebutuhan saat nasabah mengambil dananya dan menyalurkan pinjaman (kredit) kepada peminjam (debitur). Hal ini dapat dilihat dari rata-rata data dana pihak ketiga Bank Umum Syariah yang go publik tergabung dalam Buku 1 dan Buku 2 seperti pada Tabel dibawah ini

Tabel 7.

Rata-Rata Data Dana Pihak Ketiga antara Buku 1 dan Buku 2

\begin{tabular}{|c|c|c|c|c|c|c|}
\hline \multirow[b]{2}{*}{ Keterangan } & \multicolumn{2}{|c|}{ Tahun 2015} & \multicolumn{2}{|c|}{ Tahun 2016} & \multicolumn{2}{|c|}{ Tahun 2017} \\
\hline & Rata-rata DPK & $\begin{array}{c}\text { Rata-rata } \\
\text { Pembiayaan }\end{array}$ & $\begin{array}{l}\text { Rata-rata } \\
\text { DPK }\end{array}$ & $\begin{array}{c}\text { Rata-rata } \\
\text { Pembiayaan }\end{array}$ & $\begin{array}{l}\text { Rata-rata } \\
\text { DPK }\end{array}$ & $\begin{array}{l}\text { Rata-rata } \\
\text { Pembiayaan }\end{array}$ \\
\hline Buku 1 & $\operatorname{Rp} 26.051 .158$ & $\operatorname{Rp} \quad 6.623 .696$ & Rp 28.654.840 & $\begin{array}{ll}\operatorname{Rp} & 7.570 .206\end{array}$ & Rp 6.325.917 & Rp 5.683.750 \\
\hline Buku 2 & Rp 24.237.301 & $\operatorname{Rp} 13.571 .411$ & Rp 27.734.577 & $\operatorname{Rp} \quad 14.149 .966$ & $\operatorname{Rp} 65.566 .670$ & Rp 56.165.500 \\
\hline
\end{tabular}

Sumber: data diolah penulis

Dari Tabel diatas dapat dilihat bahwa rata-rata data dana pihak ketiga Bank Umum Syariah yang go publik tergabung dalam Buku 1 tahun 2015 sebesar Rp 26.051.158.086.631 dan Rp 28.654.839.571.429 tahun 2016 sera tahun 2017 Rp 6.325.917.000.000, sedangkan pembiayaan yang dimiliki sebesar Rp 655.546.142.857 untuk tahun 2015 dan tahun 2016 sebesar $\operatorname{Rp} 729.922 .142 .857$ serta Rp 568.375.000.000. Hal ini menandakan bahwa penyaluran kredit oleh Bank Umum Syariah yang go publik tergabung dalam Buku 1 selama dua tahun melebihi dari modal usaha yang dimilikinya sehingga risiko yang harus ditanggung oleh Bank Umum Syariah yang go publik tergabung dalam Buku 1 sangat besar.

Rata-rata data dana pihak ketiga Bank Umum Syariah yang go publik tergabung dalam Buku 2 tahun 2015 sebesar Rp 24.237.300.731.725 dan Rp 27.734.576.723.733 tahun 2016 serta $\mathrm{Rp}$ 65.566.670.000.000, sedangkan pembiayaan yang dimiliki sebesar Rp 1.393.239.250.000 untuk tahun 2015 dan tahun 2016 sebesar Rp 1.643.239.250.000 serta $\mathrm{Rp}$ 5.616.550.000.000. Hal ini menandakan bahwa pembiayaan yang dimiliki oleh Bank Umum Syariah yang go publik tergabung dalam Buku 2 melebihi dari penyaluran kredit dana pihak ketiga sehingga risiko yang harus ditanggung oleh Bank Umum Syariah yang go publik tergabung dalam Buku 2 sangat kecil.

\section{Return On Asset (ROA)}

Berdasarkan hasil pengolahan data, maka hasil perbandingan ROA antara Buku 1 dan Buku 2 pada Bank Umum Syariah yang go publik.

Tabel 8.

Hasil Uji Beda ROA antara Buku 1 dan Buku 2 Pada Bank Umum Syariah Go Publik

\begin{tabular}{|l|r|l|l|}
\hline \multicolumn{2}{|c|}{ Buku 1 } & \multicolumn{2}{c|}{ Buku 2 } \\
\hline \hline Rata-Rata & 1,25 & Rata-Rata & 0,89 \\
\hline SD & 1,36 & SD & 0,32 \\
\hline t-hitung & $=1,410$ \\
\hline t-tabel & $=2,052$ \\
\hline Sign. & $=0,164$ \\
\hline
\end{tabular}

Sumber: data diolah

Pengujian independen t-test dapat 
diketahui dari hasil output spss diatas. Taraf signifikansi yang digunakan dalam analisis ini menggunakan taraf signifikansi sebesar $5 \%$ atau 0,05. Kemudian menentukan nilai thitung dan ttabel. thitung dapat dilihat dari output diatas (Independent Sampel Test) yaitu sebesar 1,410 dan nilai tabel dapat sebesar 2,052. Dapat diketahui bahwa nilai $t_{\text {hitung }}<t_{\text {tabel }}$ $(1,410<2,052)$ maka $H_{a}$ ditolak dan $H_{0}$ diterima. Jadi dapat disimpulkan bahwa tidak ada perbedaan rata-rata ROA antara Buku 1 dan Buku 2 pada Bank Umum Syariah yang go publik. Nilai ratarata ROA dari Buku 1 sebesar 1,25 sedangkan nilai rata-rata ROA dari Buku 2 sebesar 0,89. Jadi nilai rata-rata ROA BukU 1 sama dengan nilai rata-rata ROA Buku 2. Hal ini menandakan bahwa tidak ada perbedaan ROA antara Bank Umum Syariah yang go publik tergabung dalam Buku 1 dan Bank Umum Syariah yang go publik tergabung dalam Buku 2. Bank Umum Syariah yang go publik tergabung dalam Buku 1 dan Bank Umum Syariah yang go publik tergabung dalam Buku 2 memiliki kemampuan yang sama dalam menghasilkan profit atau laba (profitabilitas). Fungsi dari ROA adalah untuk melihat seberapa efektif perbankan dalam menggunakan asetnya dalam menghasilkan pendapatan. Semakin besar nilai ROA artinya semakin baik kemampuan perbankan dalam menghasilkan laba, sebaliknya semakin kecil nilai ROA artinya semakin buruk kemampuan perbankan dalam menghasilkan laba. Hal ini dapat dilihat dari rata-rata data laba dan total aset Bank Umum Syariah yang go publik tergabung dalam Buku 1 dan Buku 2 seperti pada Tabel dibawah ini

Tabel 9.

\section{Rata-Rata Data Laba antara Buku 1 dan}

Buku 2

\begin{tabular}{|c|c|c|c|c|c|c|}
\hline \multirow[t]{2}{*}{ Keterangan } & \multicolumn{2}{|c|}{ Tahun 2015} & \multicolumn{2}{|c|}{ Tahun 2016} & \multicolumn{2}{|c|}{ Tahun 2017} \\
\hline & $\begin{array}{l}\text { Rata-rata } \\
\text { Laba }\end{array}$ & $\begin{array}{l}\text { Rata-rata } \\
\text { Total Aset }\end{array}$ & $\begin{array}{c}\text { Rata-rata } \\
\text { Laba }\end{array}$ & $\begin{array}{l}\text { Rata-rata } \\
\text { Total Aset }\end{array}$ & $\begin{array}{l}\text { Rata-rata } \\
\text { Laba }\end{array}$ & $\begin{array}{l}\text { Rata-rata } \\
\text { Total Aset }\end{array}$ \\
\hline Buku 1 & $\begin{array}{ll}\mathrm{Rp} & 125.420\end{array}$ & $\operatorname{Rp} 25.129 .330$ & $\begin{array}{ll}\operatorname{Rp} & 426.000\end{array}$ & $\operatorname{Rp} \quad 18.917 .000$ & $\operatorname{Rp} \quad 53.600$ & $\operatorname{Rp} 7.765 .000$ \\
\hline Buku 2 & Rp 1.032 .000 & Rp 168.236 .000 & Rp 1.129 .000 & Rp 124.375 .000 & $\operatorname{Rp} 1.103 .250$ & $\operatorname{Rp} 79.261 .170$ \\
\hline
\end{tabular}

Sumber: data diolah penulis

Dari Tabel diatas dapat dilihat bahwa rata-rata laba Bank Umum Syariah yang go publik tergabung dalam Buku 1 tahun 2015 sebesar Rp 125.420.000.000, Rp 426.000.000.000 tahun 2016 sera tahun 2017 Rp 53.600.000.000, sedangkan ratarata total aset yang dimiliki sebesar Rp 25.129.330.000 untuk tahun 2015 dan tahun 2016 sebesar Rp 18.917.000.000 serta Rp 7.765.000.000. Hal ini menandakan bahwa laba yang dimiliki oleh Bank Umum Syariah yang go publik tergabung dalam Buku 1 selama tiga tahun kurang dari asset yang dimilikinya sehingga Bank Umum Syariah yang go publik tergabung dalam Buku 1 profitabilitas yang dimilikinya masih rendah.

Rata-rata laba Bank Umum Syariah yang go publik tergabung dalam Buku 2 tahun 2015 sebesar Rp 1.032.000.000. dan Rp 1.129.000.000 tahun 2016 serta Rp 1.103.250.000, sedangkan total aset yang dimiliki sebesar Rp 168.236.000.000 untuk tahun 2015 dan tahun 2016 sebesar Rp 
124.375.000.000 serta Rp 79.261.170 tahun 2017. Hal ini menandakan bahwa ROA yang dimiliki oleh Bank Umum Syariah yang go publik tergabung dalam Buku 2 masih belum maksimal, hal ini ditandai dengan rata-rata laba yang dihasilkan lebih kecil dari asset yang dimiliki oleh Bank Umum Syariah yang go publik tergabung dalam Buku 2.

\section{SIMPULAN}

Hasil penelitian dan pembahasan yang digunakan sesuai dengan tujuan hipotesis yang dilakukan maka dapat ditarik kesimpulan sebagai berikut:

1. Terdapat perbedaan Capital Adequacy Ratio antara Buku 1 dan Buku 2 pada Bank Umum Syariah yang go public. Nilai thitung $>t_{\text {tabel }}(8,067>$ $2,052)$ maka $\mathrm{Ha}_{a}$ diterima dan $\mathrm{H}_{0}$ ditolak. Jadi dapat disimpulkan bahwa ada perbedaan rata-rata CAR antara BukU 1 dan Buku 2 pada Bank Umum Syariah yang go publik.

2. Terdapat perbedaan Belanja Operasional terhadap Pendapatan Operasional antara Buku 1 dan Buku 2 pada Bank Umum Syariah yang go public. Nilai thitung $>t_{\text {tabel }}(3,042>2,052)$ maka $\mathrm{Ha}_{a}$ diterima dan $\mathrm{H}_{0}$ ditolak. Jadi dapat disimpulkan bahwa ada perbedaan rata-rata BOPO antara Buku 1 dan Buku 2 pada Bank Umum Syariah yang go publik.

3. Terdapat perbedaan Loan to Deposits Ratio antara Buku 1 dan Buku 2 pada Bank Umum Syariah yang go public. Nilai thitung $>$ tabel $(7,365>2,052)$ maka
$\mathrm{H}_{\mathrm{a}}$ diterima dan $\mathrm{H}_{0}$ ditolak. Jadi dapat disimpulkan bahwa ada perbedaan rata-rata LDR antara Buku 1 dan BukU 2 pada Bank Umum Syariah yang go publik.

4. Tidak terdapat perbedaan Return On Assets antara Buku 1 dan Buku 2 pada Bank Umum Syariah yang go public. Nilai thitung $<t_{\text {tabel }}(1,410<2,052)$ maka $\mathrm{H}_{\mathrm{a}}$ ditolak dan $\mathrm{H}_{0}$ diterima. Jadi dapat disimpulkan bahwa tidak ada perbedaan rata-rata ROA antara BukU 1 dan Buku 2 pada Bank Umum Syariah yang go publik.

\section{DAFTAR PUSTAKA}

2015 Laporan Kevangan Publikasi Bank 2015-2017. Jakarta: 2015. Direktori Perbankan Indonesia $2014 . \quad$ Jakarta: http://www.bi.go.id//

Anindita, Irma. 2011. Analisis Pengaruh Tingkat Suku Bung, CAR, NPL, dan LDR terhadap Penyaluran Kredit UMKM (Studi pada Bank Umum Swasta Nasional Periode 20032010).

Ayuningrum, Anggrainy Putri. 2011. Analisis Pengaruh CAR, NPL, BOPO, NIM, dan LDR Terhadap ROA (Studi pada Bank Umum Go Public yang Listed pada Bursa Efek Indonesia Tahun 2005-2009). Skripsi tidak diterbitkan. Semarang Fakultas Ekonomi Universitas Diponegoro.

Bank Indonesia. 2004. Peraturan Bank Indonesia Nomor 6/10/PBI/2004 
Tentang Sistem Penilaian Tingkat Kesehatan Bank Umum.

Bank Indonesia. 2012. Peraturan Bank Indonesia (PBI) Nomor 14/26/pbi/2012 tentang Kegiatan Usaha dan Jaringan Kantor Berdasarkan Modal Inti Bank. Jakarta: http//www.bi.go.id//

Bratadharma, Angga. 2014. Daya Saing Bank Kategori BUKU 1 Rendah, (Online), (http://www.infobanknews .com/2014/08/daya-saing-bank-

kategoribuku-i-rendah/, diakses pada 30 November 2014).

http://www.http://www.bi.go.id//

Huda,Nurul dan Mohamad Heykal. 2010. Lembaga Kevangan Islam Tinjauan Teoritis dan Praktis. Jakarta: Kencana Prenada Media Group Ismail. 2011. Perbankan Syariah. Jakarta: Kencana Prenada Media Group.

Kasbal, Sri Wahyuni. 2012. Analisis Pengaruh Capital Adequacy Ratio (CAR),

Non Performing Loan (NPL), Loan to Deposit Ratio (LDR), Net Interest Margin (NIM), dan Rasio Beban Operasional Terhadap Pendapatan

Operasional (BOPO) Terhadap Profitabilitas pada Perusahaan Perbankan di Indonesia (Studi Kasus Bank Devisa Periode 20062010). Skripsi tidak diterbitkan. Makassar Fakultas Ekonomi dan Bisnis Universitas Hasanuddin.
Kuncoro, Mudrajad. 2002. Manajemen Perbankan: Teori dan Aplikasi. Yogyakarta: BPFE.

Rizkita, Andra. 2013. Analisis Pengaruh CAR, BOPO, NIM, NPL, dan LDR Terhadap Perubahan Laba Perbankan yang Terdaftar di BEI. Jurnal Dinamika Manajemen, Vol. 2 No. 7 (3): 65-80

Statistik perbankan Indonesia --http://www.ojk.go.id/id/kanal/per bankan/data-dan-statistik/statistikperbankan-indonesia

Sumitro, Warkum. 2002. Asas-asas Perbankan Islam dan LembagaLembaga Terkait BMI dan Takaful) di Indonesia. Jakarta: RajaGrafindo Persada

Wibowo, Edy dkk. 2005. Mengapa Memilih Bank Syariah, Cetakan Pertama, Halaman 33. Bogor: Ghalia Indonesia.

Peraturan Bank Indonesia (PBI). 27 Desember, 2012. PERATURAN BANK INDONESIA NOMOR 14/26/PBI/2012 TENTANG KEGIATAN USAHA DAN JARINGAN KANTOR BERDASARKAN MODAL INTI BANK (Online). (http://www.bi.go.id/id/peraturan/ perbankan/Documents/b510cf302 92c45428e25e1466e81525fpbi_142 612mergel.PDF diakses 19 September 2017).

Erlina Dwi Syafira. 2011. Pengaruh CAR, NPL, LDR, NIM, DAN SIZE Terhadap Risiko Bisnis Bank (Studi Komparatif Bank Umum Go Publik dan Bank 
Setiahani, et al/Jurnal Ekonomi Syariah Teori dan Terapan Vol. 6 No. 7 Juli 2019: 1331-1347;

PERBANDINGAN KINERJA KEUANGAN BERDASARKAN KATEGORI BUKU

Umum Non Go Publik di Indonesia

Tahun 2004-2008).

Fahmi Noviyandi. Analisis Pengaruh Loan

To Deposit Ratio Dan

Makroekonomi Terhadap

Profitabilitas Perbankan Umum

Syariah Di Indonesia Periode

2004q1-2009q4.

Takarani, Nurjanti dan Erni Ekawati. 2003.

Analisis Rasio Kevangan Dalam

Memprediksi Perubahan Laba

Pada Perusahaan Manufaktur Di

Pasar Modal Indonesia. Jurnal

Ekonomi Bisnis Dan Akuntansi. Vol.

6,No 3. 